\title{
The Short-Term Impact of COVID-19 on Global Stock Market Indices
}

Gurmeet Singh ${ }^{1}$, Muneer Shaik²

ABSTRACT

The COVID-19 pandemic, declared on March 11, 2020 by the World Health Organisation (WHO), has had a severe economic and financial impact on every economy around the world. This paper aims to analyze the short-term impact of COVID-19 on global financial stock market indices. We study the impact of six different WHO announcements regarding COVID-19 on five different sectors (Pharma, Healthcare, Information Technology, Hotel \& Airline) based on the indices of three different economies (World, Developed and Emerging economy). We also study the movement of stock prices and volume of nine different global stock market indices (classified as developed \& emerging) based on the number of new cases and deaths due to COVID-19. The study's findings suggest that there is a significant effect of COVID-19 on global financial stock markets. However, the effect is varied for developed and emerging economies.

KEY WORDS: $\quad$ COVID-19, Stock Market Index, Sectoral Analysis, Cumulative Abnormal Returns, International Financial Markets.

JEL Classification: G14, G12, G15.

Research Scholar, IFMR Graduate School of Business

${ }^{2}$ Assistant Professor, IFMR Graduate School of Business

\section{Introduction}

Financial market participants were forming opinions about the market-moving events such as the US-China trade deal and the US presidential election before the start of 2020 . However, quite a bit has changed in the global markets and future expectations due to the sudden outbreak of the coronavirus , subsequently termed as COVID-19 by the World Health Organization (World Health Organization [WHO], 2020a). COVID-19 is an airborne illness that is highly transmittable between humans which primarily targets the human respiratory system (Hussin et al., 2020). Currently, COVID-19 has taken control of the global markets. Various industries around the world have been shut. COVID-19 cases have been increasing dramatically in Asia and other parts of the world because of the high infection rate.

Correspondence concerning this article should be addressed to: Gurmeet Sigh, IFMR Graduate School of Business, Krea University, No. 196, TTK Road, Parthasarathy Gardens, Alwarpet, Chennai, 600018. E-mail: gurmeet.singh@ifmr.ac.in
There is a lot of uncertainty about how long the patients remain infectious and how long they must be quarantined and isolated.

The COVID-19 epidemic began in Wuhan in early December of 2019 when people were exposed to an unidentified source at a seafood market and started falling ill. The market was quickly closed down. Until 20th January 2020, the total number of cases was around 50. However, there was a sudden surge in the number of cases after 20th January 2020, and the stock markets, which were hovering near a record high, started to feel the pinch. The coronavirus induced a panic in the stock markets around the globe and the traders got nervous and anxious. Companies began to close stores, cancel travel, and stop all operation in the affected regions of China. The local outbreak quickly turned into a global pandemic on March 11, 2020. In March, Europe and the US have become the hot spots of coronavirus due to the increase in the number of confirmed cases. As of April 14, 2020, there are about 1.7 million confirmed 
cases of the coronavirus in 185 countries, and more than 100000 have lost their lives (World Health Organization, 2020b). Serious efforts have been implemented since, such as tax reliefs, additional funding for the healthcare sector, economic stimulus packages, lower interest rate, financial support by international institutions and local government to help revive the economy and fight COVID-19 (International Monetary Fund, 2020; WHO, 2020c).

The authorities are quick to respond to coronavirus cases and impose quarantines in affected areas. WHO and the local governments provided regular guidelines to reduce uncertainty. However, the stock markets are extremely volatile at the time. Thus, it would be interesting to compare the stock market reaction to COVID-19 announcements made by the WHO. Accordingly, the purpose of the current study is to examine the impact of COVID-19 on sectors that are sensitive to the outbreak, such as Pharma, Information Technology, Healthcare, Airline, Hotel and Leisure from January 2020 to March 2020 for developed and emerging economies. The reason for comparing the emerging economies with the developed economies stems from the differences in healthcare infrastructure facilities to combat COVID-19 (Knox, 2020). The emerging economies face many challenges such as shortage of quarantine facilities, lesser number of testing labs, shortage in personal protective equipment such as N95 masks, gloves, medical gowns, eye protection, etc., and a low level of public awareness and hygiene (Gash, 2020; Al-Jumaili and Mikhae, 2020). Most of the emerging countries' healthcare systems are severely stretched with limited financing. There is a shortage of intensive care units. For example, India has the lowest healthcare expenditure in the world, as it stands, at $1.3 \%$ of GDP. Considering India's population of 1.38 billion, a potential outbreak is a serious concern. Hence, many countries in the Asian region have adopted strict measures, such as closing borders, mandatory quarantine, and lockdown for extended periods to try and stop the spread of the disease until effective control measures are developed, such as a vaccine. However, with all strings attached, such measures will have a financial and economic impact on various sectors such as Hotel and Leisure, Travel and Transportation, Pharma and Healthcare, etc.
There is a history of previous pandemics which have occurred worldwide and killed millions. In 1918 the global influenza pandemic affected onethird of the world population and killed approximately 40 million worldwide. There was also the Ebola outbreak, which killed around 11,300 people. The COVID-19 outbreak is compared with the 2002-2004 SARS (Severe Acute Respiratory Syndrome) outbreak. The SARS outbreak, which is also similar to COVID-19, originated in Guangdong province, China in 2002 and it spread to 26 countries around the world in a matter of weeks (Wang and Jolly, 2004). According to a CNN report, the number of outbound tourists in China increased from 16.6 million trips in 2003 to 149.7 million in 2018 (Hollingsworth, 2020). This is one of the factors which highlight how the COVID-19 outbreak has spread far more quickly than the 2002-2004 SARS outbreak. Few studies have also investigated the effect of SARS on the stock market. For example, Nippani and Washer (2004) examined the impact of SARS. on several countries' stock markets indices using Mann-Whitney non-parametric tests. The current crisis of COVID-19 shows how an outbreak that originated in Wuhan can cause triggers and shockwaves to the health, economic, and financial systems of other nations due to growing globalization. It has spread so fast because millions of people traveled across and outside China to celebrate Lunar new year.

The Global debt-to-GDP ratio is at an all-time high of 322 percent (Tanzi, 2020). Massive financial resources would have to be pumped into the healthcare sector quickly to combat COVID-19. The travel restriction, business closure, and quarantine would pose a serious economic problem and would also affect personal incomes. The losses in wages or income will be felt most by the people employed in the informal economy where there is no paid leave. A recent report by the International Labor Organization (2018) shows that 60 percent of the world's employed population work in the informal sector. According to the report, 2 billion people work informally, most of these workers are in emerging countries.

Oil prices have also taken the hit from the slowdown in economic activity and due to the ongoing price war between Saudi Arabia and Russia. The 
decrease in oil prices has affected the energy sector severely. The strict measures adopted to contain the COVID-19 pandemic, such as lockdown, social distancing, closure, and shutdown of schools, shops, etc., will result in individuals making fewer trips to the market, travel will decrease, as well as other social activities (Whitworth, 2020). These measures will have an impact on all the sectors of the economy. The structure of the economy has also changed over time: the service sector now dominates, many areas of which involve face to face interaction (Central Intelligence Agency, 2018). According to the CIA report, the contribution of services to GDP stands at $63 \%$ for the world economy. An abrupt lockdown and social distancing will bring in a sharp drop in demand for such services. Hence, there are tremendous repercussions on all the sectors of the economy. However, the current study only considers sectors directly affected by COVID-19, such as airline, hotels, tourism, pharma, etc. Sectors such as metal, energy, banking, financial services, etc., are mostly affected via the economic channel due to the cyclical nature of their dependence on the economy. The business cycle, which is the pattern of most of these sectors take months or even year to determine the asset market returns. Hence, we only look at the short-term stock market reaction of the sector directly affected by COVID-19.

Against this backdrop, the present study examines the short-term market reaction of COVID-19 for emerging and developed markets. Firstly, we begin our analysis by examining the Cumulative Abnormal Return (CAR) for different actions around event days. We try to determine if some sectors show more abnormal returns over the event window than others. Secondly, we investigate if there is a difference in the magnitude across global stock markets. We check how the stock market indices and volume (i.e., the total number of shares traded) moved in relation to confirmed cases and deaths. The reason for studying volume could be many; for example, there could be panic selling by a large number of investors, which could put more downward pressure on the stock prices. However, there could be a decrease in volume as traders or market participants cannot go to work because of a lockdown or various other reasons. For example, NYSE announced it would temporarily close its trading floor after two people tested positive for coronavirus (Messamore, 2020). NYSE also suspended open-outcry trading and placing an order through floor broker.

The current paper uses an event study-based approach to examine the effect of COVID-19 in the stock market by measuring cumulative abnormal returns for $\mathrm{WHO}$ announcements related to $\mathrm{COV}$ ID-19. The study also checks for the impact of confirmed cases on the stock market for both the emerging and developed economies. The study is expected to contribute to the body of knowledge regarding the impact of the coronavirus outbreak on the stock market and provide needed insights to market participants to manage their investment decision around such pandemic outbreaks strategically.

\section{Data}

For conducting the event study, we have used two sets of data from January 2020 to March 2020. Firstly, we took the daily closing price of 5 sectoral indices based on the Morgan Stanley Capital International All Country World Index (MSCI ACWI Index), MSCI World index and MSCI Emerging markets index. We chose the following sectors: Pharma, Healthcare, Hotel and Leisure, Airline, and Information Technology. Secondly, we used the daily closing price of the market index of the MSCI ACWI Index, MSCI World, MSCI Emerging markets. The data used for analyzing the sectoral impact of COVID-19 has been taken from Bloomberg.

The MSCI ACWI index captures large and mid-cap representation across 23 Developed Markets (DM) and 26 Emerging Markets (EM) countries. The Developed markets include: Australia, Austria, Belgium, Canada, Denmark, Finland, France, Germany, Hong Kong, Ireland, Israel, Italy, Japan, Netherlands, New Zealand, Norway, Portugal, Singapore, Spain, Sweden, Switzerland, the UK, and the US. The Emerging markets include Argentina, Brazil, Chile, China, Colombia, Czech Republic, Egypt, Greece, Hungary, India, Indonesia, Korea, Malaysia, Mexico, Pakistan, Peru, Philippines, Poland, Qatar, Russia, Saudi Arabia, South Africa, Taiwan, Thailand, Turkey, and United Arab Emirates. MSCI ACWI is a proxy for the world economy. With 3,047 constituents, the index covers approximately $85 \%$ of the global investable equity op- 
portunity set. The top 10 constituents are Microsoft Corp, Apple, Amazon, Facebook A, Alphabet C, Alphabet A, Johnson \& Johnson, Alibaba Group, Nestle, JP Morgan \& Chase. Sectors chosen are MSCI AWCI Pharma, MSCI AWCI Healthcare, MSCI AWCI Airline, MSCI AWCI Hotel and Leisure, and MSCI AWCI Information Technology.

The MSCI World Index captures large and midcap representation across 23 Developed Market (DM) countries. The 23 Developed market countries are the same as in the MSCI ACWI Index. With 1,643 constituents, the index covers approximately $85 \%$ of the free float-adjusted market capitalization in each country. The top 10 constituents for the MSCI World index are Microsoft, Apple, Amazon, Facebook A, Alphabet C, Alphabet A, Johnson \& Johnson, Nestle, JP Morgan Chase, and Visa. MSCI World is a proxy for a developed market. Sectors chosen are MSCI World Pharma, MSCI World Healthcare, MSCI World Airline, MSCI World Hotel and Leisure, and MSCI World Information Technology.

The MSCI Emerging Markets Index captures large and mid-cap representation across 26 Emerging Market (EM) countries. The 26 emerging markets countries are the same as in the MSCI ACWI index. With 1,404 constituents, the index covers approximately $85 \%$ of the free float-adjusted market capitalization in each country. Top 10 holdings of MSCI emerging markets are Alibaba Group, Tencent Holdings, Taiwan Semiconductor MFG, Samsung electronics, China construction, Naspers, Ping an Insurance, China Mo- bile, ICBC H, Reliance Industries. MSCI Emerging markets are a proxy for emerging markets. Sectors chosen are MSCI Emerging Markets Pharma, MSCI Emerging Markets Healthcare, MSCI Emerging Markets Airline, MSCI Emerging Markets Hotel and Leisure, and MSCI Emerging Markets Information Technology. Further details about the sector allocation and country weights for the three indices are provided in the Appendix. Table 1 shows the summary of the datasets that we have used for our analysis.

To analyze the effect of COVID-19 on global stock market indices, we have taken the daily closing price and volume of the following stock market indices listed below from Bloomberg. The study examines the effect of COVID-19 from December 2019 to April 2020. Table 2 shows the details of the name of the stock index and the corresponding country classified as developed and emerging economies.

In this study, we had a total of six sample events for COVID-19. The list of announcements made by WHO is given in Table 3.

\section{Methodology}

The methodology used in this study to understand the relationship between COVID-19 \& stock market returns is an event study analysis. According to Mackinlay (1997), the event study can be used to find the effect of a particular event. Event study has been widely used to check the stock price movement around an event (Ball and Brown 1968; Dolley 1993; Fama 1981). Using the same approach, we check for the impact of

Table 1. Summary of the Data Sets Included in the Study for Sectorial Analysis Based on WHO Announcements

\begin{tabular}{|c|c|c|c|c|}
\hline S.No & Stock Index & Acts as a proxy for & $\begin{array}{c}\text { Number of coun- } \\
\text { tries }\end{array}$ & List of sectors \\
\hline 1 & MSCI ACWI & World Economy & 49 & 5 \\
\hline 2 & MSCI World & $\begin{array}{c}\text { Developed Econo- } \\
\text { mies }\end{array}$ & 23 & 5 \\
\hline 3 & MSCI EM & Emerging Economies & 26 & 5 \\
\hline
\end{tabular}


Table 2. Summary of the Global Stock Indices Included in the Study

\begin{tabular}{lcc}
\hline STOCK MARKET INDEX & COUNTRY \\
\hline Emerging Economies & NIFTY 50 & India \\
& SHCOMP & China \\
& JCI & Indonesia \\
Developed Economies & DJI & U.K. \\
& FTSE & France \\
& CAC & Germany \\
& DAX & Jorea \\
\hline
\end{tabular}

Table 3. World Health Organization Major Announcements for COVID-19 Timeline

\section{Announcements}

1. Jan 22, 2020: WHO meets to discuss whether to declare the outbreak an international health emergency.

2. Jan 30, 2020: WHO declares the coronavirus outbreak as a Public Health Emergency of International Concern (PHEIC).

3. Feb 5, 2020: WHO launches a $\$ 675$ million preparedness and response plan for February through April 2020 to prevent the further spread of the coronavirus and protect states with weaker health systems.

4. Feb 15, 2020: WHO Director-General addresses the Munich Security Conference about COVID-19, warning that the pathogen has pandemic potential.

5. Feb 26, 2020: WHO announces that February 25 was the first day there was more new cases outside of China than from China. 
the COVID-19 announcement made by WHO on stock market returns for developed and emerging nations. According to Efficient Market Hypothesis $(\mathrm{EMH})$, the stock prices should reflect all available information that is publicly and privately available, which means there should be no abnormal returns. We check if the announcement made by WHO creates any abnormal return in the stock market.

The timeline used for the event study is shown in Figure 1 which includes the event date (announcement date), test period/ event window, and estimation window.

We perform the following steps for an event study. First, we identify the events based on the announcements made by WHO related to COVID-19. We then identify the estimation period, event date, and post-event window. In our study, the event date is day 0 , the event window is 10 days ( 5 days before and 5 days after the event date), the estimation period is 90 days (starts 100 days before and ends 10 days before the event date). There is a 5 days gap between the end of the estimation window and start of the event window to avoid any noise. To study the effect of COVID-19 announcement on stock returns, we look at returns instead of share prices.

Hence, we calculated the log-returns using the formula:

$$
\text { Return }_{t}=\ln \left(\frac{\text { Price }_{t}}{\text { Price }_{t-1}}\right)
$$

From the data in the estimation window we calculate the parameters 'alpha' and 'beta' as suggested by Brown and Warner (1985). Once we estimate the parameter, we calculated expected return using the market model formula:

$$
E(R)_{t}=\propto_{t}+\beta_{t} R_{m, t}
$$

The key assumption of the event study methodology is that markets must be efficient, and there should be no abnormal return. Hence, we measure abnormal returns in the event window. Abnormal return is the difference between the actual return observed during the event window and expected return during the estimation window. The abnormal return is calculated using the following formula:
$A R_{t}=R_{t}-E(R)_{t}$

$A R_{t}$ : is the abnormal return at time $t$

$R_{t}$ : is the actual or observed return at time $t$

$E(R)_{t}$ : is the expected return at time $t$ calculated using the market model.

Here, the null hypothesis is: $H_{0}: \mathrm{AR}=0$

To better understand the effect of COVID-19 on stock markets, we then add up the abnormal return over the entire period of event window ( $t_{1}$ to $t_{2}$ ) to get the cumulative abnormal return.

$\operatorname{CAR}\left(t_{1}, t_{2}\right)=\Sigma_{t_{1}, t_{2}} A R$

In this paper, we see the impact of COVID-19 on the stock markets from January 2020 to March 2020. We have conducted event study based on the 6 different announcements of WHO related to COVID-19 on sectoral indices of MSCI ACWI index, MSCI World, MSCI Emerging markets. We study the impact on sectors that are most likely to be affected due to COVID-19. We study Pharma, Healthcare, Airline, Hotel and Leisure, and Information technology. We use Event study methodology to calculate cumulative abnormal return around the event dates and check for the short-term impact created by coronavirus on various sectors in the emerging and developed economies.

We also conduct an analysis of global stock market indices like NIFTY 50, SHCOMP, JCI, SET, DAX, CAC, DJI, NKY, KOSPI, STI. We check for the movement of the stock market index and volume of emerging and developed economies for the time period December 2019 to March 2020. We check if there is any relationship between the stock market index, volume, confirmed cases, and death reported for COVID-19.

\section{Empirical Findings}

\subsection{Analysis on five sectors of the three different glob-} al economies based on six WHO announcements.

Workers all around the world are staying at home due to the measures adopted to stop COVID-19. This will lead to lower consumer spending, and there will also be a supply chain disruption. People will dine out less and vacations will be postponed. Industries related to 


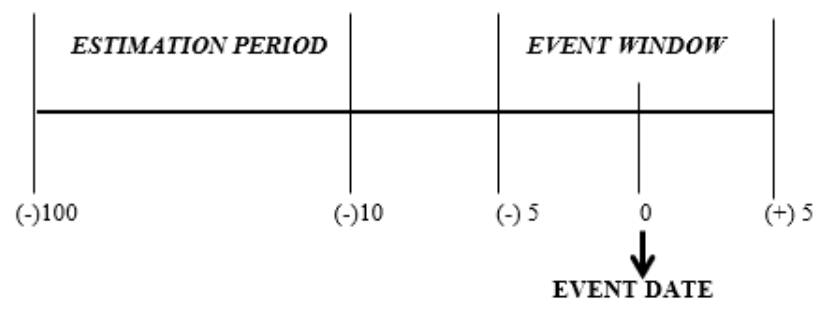

Figure 1. Timeline for an event study.

airlines, restaurants, travel, tourism, etc. will start to lose revenue, which will eventually reflect it on balance sheet. There are both supply and demand-side disruption. However, we are also interested in knowing the short-term reaction of COVID-19 on various sectors that drive the economy.

We perform analysis of five different sectors (Pharma, Healthcare, IT, Hotel and Airline) for three different global economies like developed (MSCI World Index), emerging (MSCI EM Index), and world (MSCI ACWI Index) economy. For all the three global economies, we calculate CAR (cumulative abnormal returns) during the event period based on the six different WHO announcement dates (i.e., as on 22-01-2020, 30-01-2020, 05-02-2020, 15-022020, 26-02-2020, and 11-03-2020). The findings of the analysis are shown in Figure A.

Figure A.1 shows the cumulative abnormal returns (CAR) based on the event day, 22nd January 2020. On this day, WHO met to discuss whether to declare the outbreak as an international health emergency. Developed markets were more stable than the emerging markets as the outbreak was mostly limited to the emerging markets; especially China during this period. The Airline sector was the worst hit for both the markets as it gave a negative abnormal return of 6 percent during the event window; the hotel sector was also hit badly in the emerging markets as the outbreak was still limited. For example, the Chinese hotel market witnessed a 75\% year-over-year decline of occupancy in January, which is supposed to be a peak season due to the lunar new year (Baker, 2020). Healthcare and Pharma sectors saw strong cumulative abnormal returns due to the anticipation of growing revenue as more people would need treatment due to the outbreak. The world economy saw a large negative CAR for airline stock.

On 30th January 2020, WHO declared the coronavirus outbreak as a Public Health Emergency of International Concern (PHEIC). This news should have triggered the sectors that are most likely to be directly impacted by COVID-19. In Figure A.2, developed markets showed negative abnormal returns except for the IT sector. Emerging Markets showed positive CAR for pharma and healthcare due to the increase in the number of confirmed cases from 1297 to 20471 . More patients would require medicines and a higher number of people being admitted to hospitals. The hotel was the worst-hit sector during this event window with a negative CAR of 3 percent. The 
Figure A.1: January 22, 2020

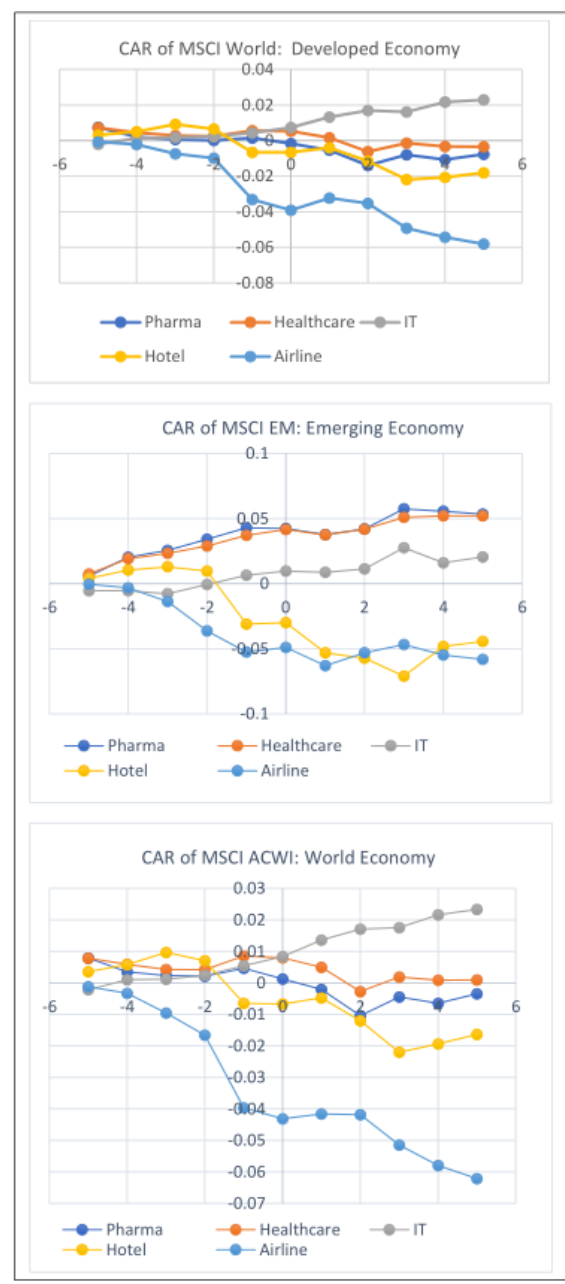

Figure A.2: January 30, 2020

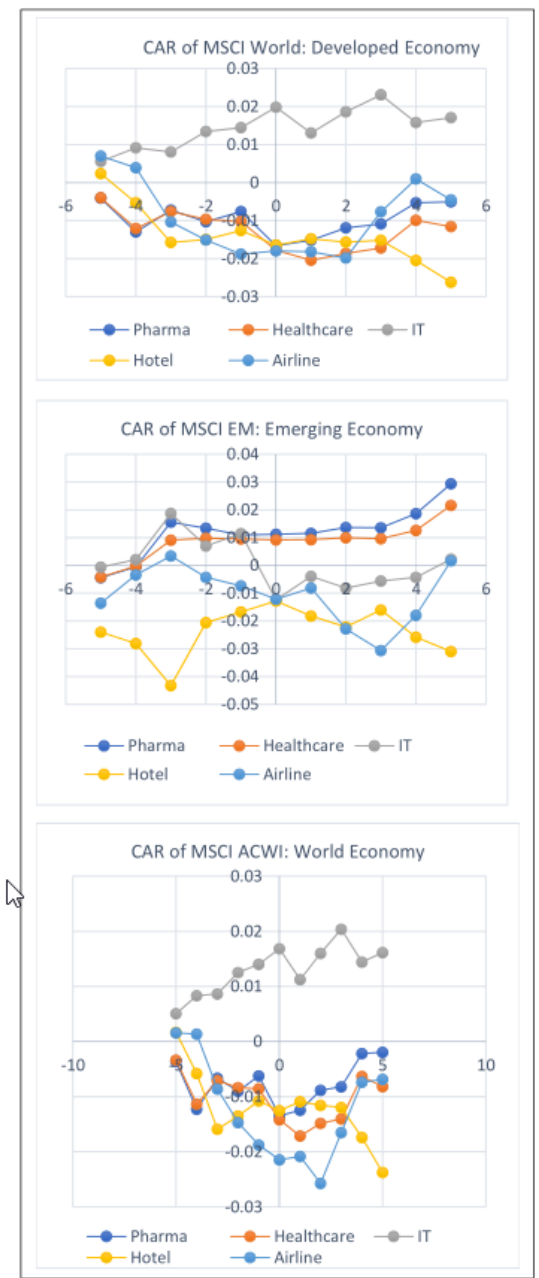

Figure A. Sectoral analysis based on Cumulative Abnormal Returns (CAR) for the three global economies for COVID-19 announcements made by WHO.

developed markets showed negative CAR for all sectors except IT. For the world economy, all the sectors gave negative CAR expects IT.

As the virus was increasing at an unprecedented speed, the WHO, on 5th February 2020, launched a $\$ 675$ million preparedness and response plan for February through April 2020 to prevent the further spread of the coronavirus and protect states with weaker health systems. Looking at Figure A.3, both the emerging and developed markets showed increased volatility due to the uncertainty that looms over the outbreak. The word pandemic scares everyone, not just the stock market, as it would mean the virus is spreading not only in China but spreading globally. All the sectors of developed, emerging, and the world economy show increase in volatility.

On 15th February, 2020, the WHO Director-General addresses the Munich Security Conference about CO- 

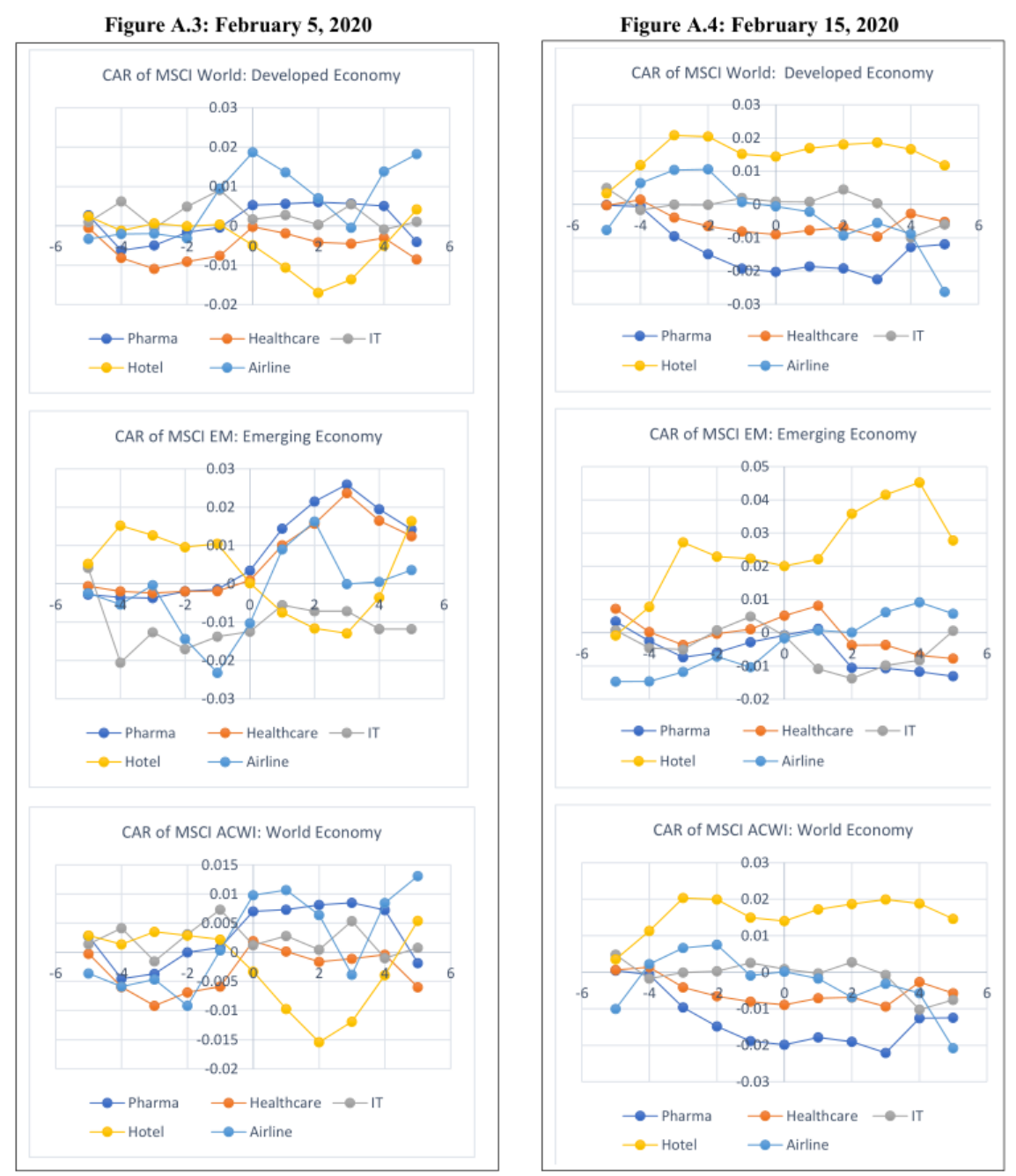

Figure A. Sectoral analysis based on Cumulative Abnormal Returns (CAR) for the three global economies for COVID-19 announcements made by WHO. (Continued)

VID-19, warning that the pathogen has pandemic potential. Looking at Figure A.4, we find the first instance where the developed markets show relatively higher CAR (cumulative abnormal return), with the airline industry being the worst performer. Surprisingly, the hotel industry seems to outperform in both developed and emerging markets significantly. The outperformance could be due to the correction because till that date, the Hotel industry index for both developed and emerging countries over the past three months has lost around 40 percent value. The world economy shows a similar finding with the Hotel sector being the outperformer with a positive CAR of around 2 percent and others giving negative CAR.

On 26th February, 2020, WHO announces that 25th February,2020 was the first day when there are more new cases outside of China than from China. Looking at Figure A.5, the CAR for the developed market is 
Figure A.5: February 26, 2020

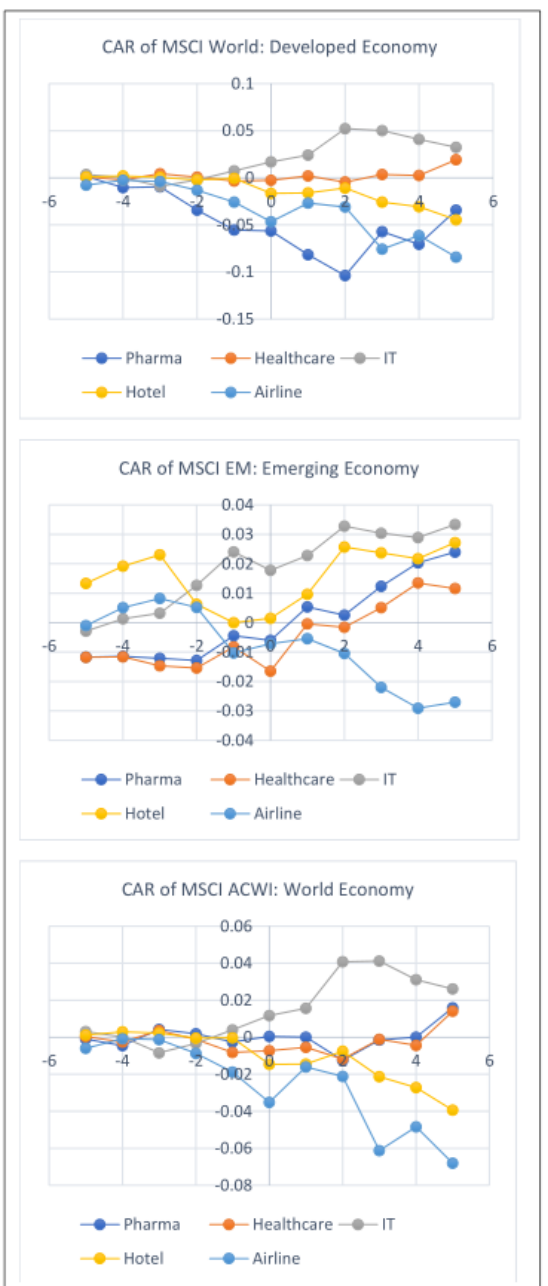

Figure A.6: March 11, 2020

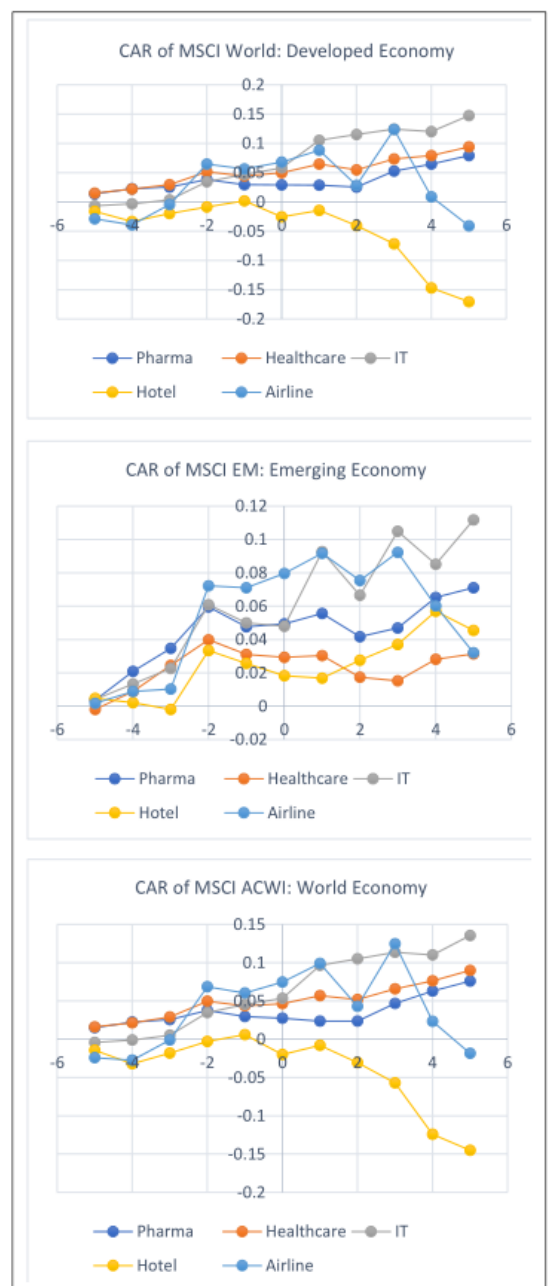

Figure A. Sectoral analysis based on Cumulative Abnormal Returns (CAR) for the three global economies for COVID-19 announcements made by WHO. (Continued)

negative compared to emerging markets showing the presence of COVID-19 globally and not just in emerging economies. The airline sector is giving maximum negative returns across developed, emerging, and world economy. The Airline sectors show a negative CAR of $7 \%$ for the world economy.

After two weeks, on 11th March, 2020, coronavirus is declared as a pandemic by WHO. Looking at Figure
A.6, we can observe that all sectors have performed well for emerging economies. Except for airlines, all the sectors show positive CAR for the developed and World economy. The airline industry stocks have fallen by a massive 18 percent for a developed economy and 16 percent for emerging economies. The airline, Pharma, Hotel, and Tourism, IT performed well during this event window compared to the market indices. The rea- 


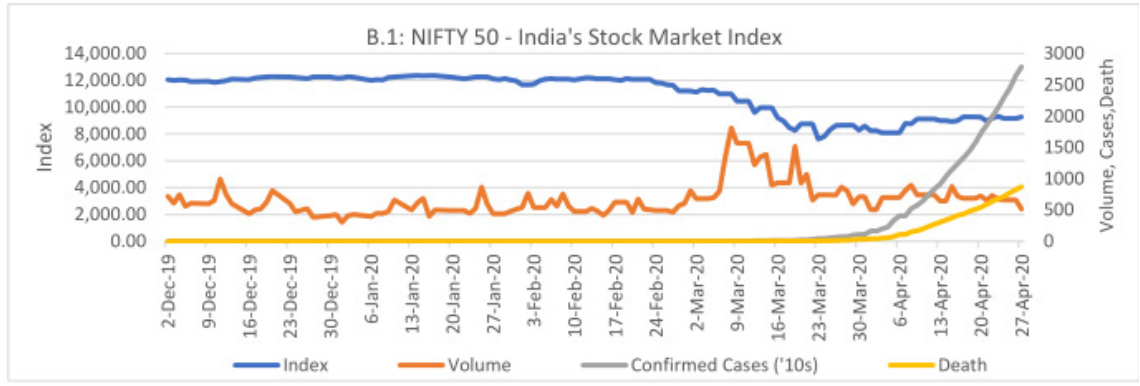

Note: Volume is in millions.

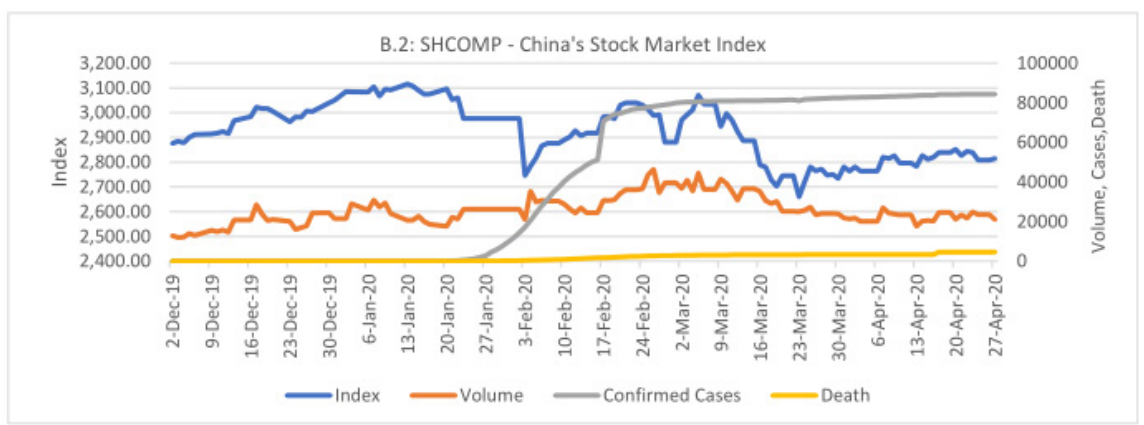

Note: Volume is in millions

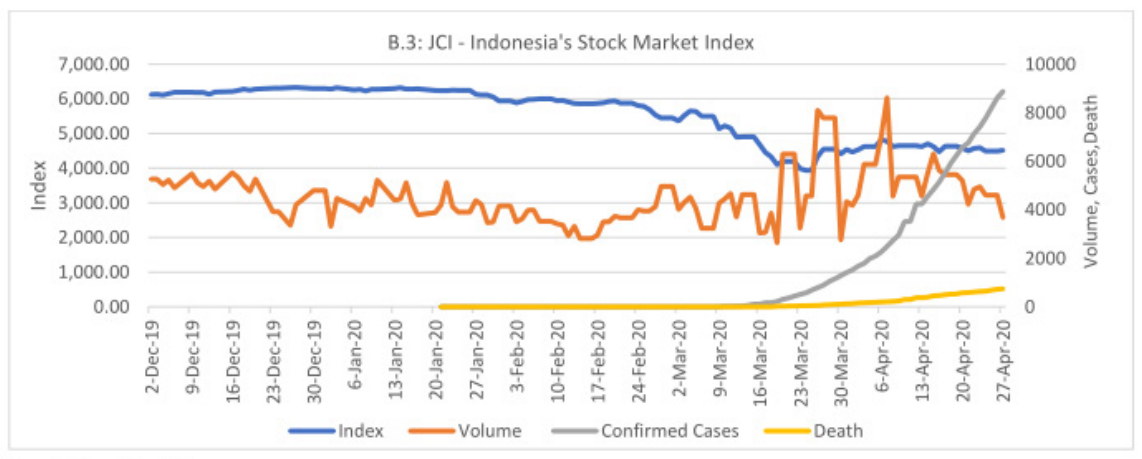

Note: Volume is in million

Figure B. Effect of COVID-19 on three Emerging Nation stock market indices.

son for this could be various other sectors move with the economy, such as Manufacturing, Banking, and Finance, Auto industry, etc., which have started to fall as a result of growing concern surrounding this pandemic. For example, due to the decrease in energy price and China being the largest importer of commodities, the energy sector has started to show the pessimistic view, along with the manufacturing sector due to the strin- gent lockdown measure that is being followed everywhere around the world. We can confidently say sectors such as Hotel, Airline, Pharma, Healthcare, Information Technology have exhibited considerable market inefficiency.

The effect of COVID-19 has slowly moved from emerging to developed markets as the outbreak was called a pandemic on March 11, 2020. On observation, 


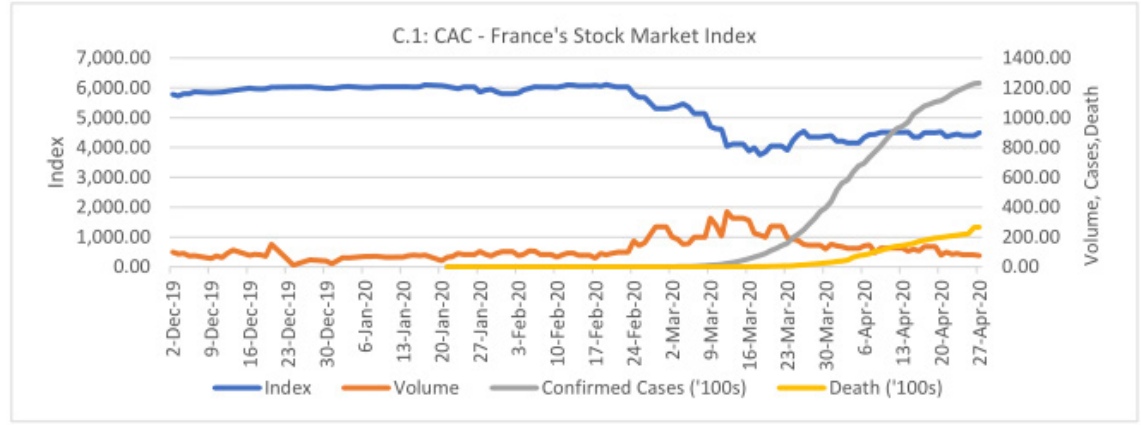

Note: Volume is in millions

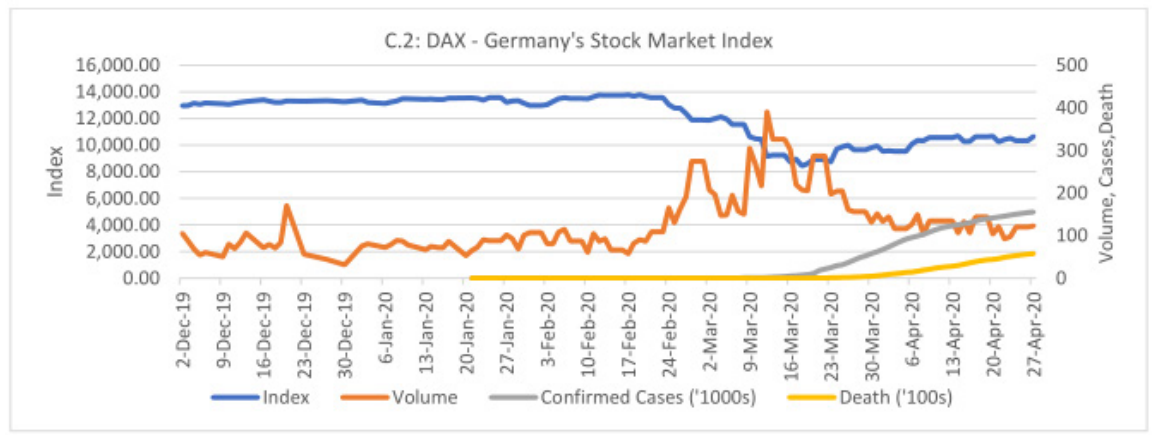

Note: Volume is in millions

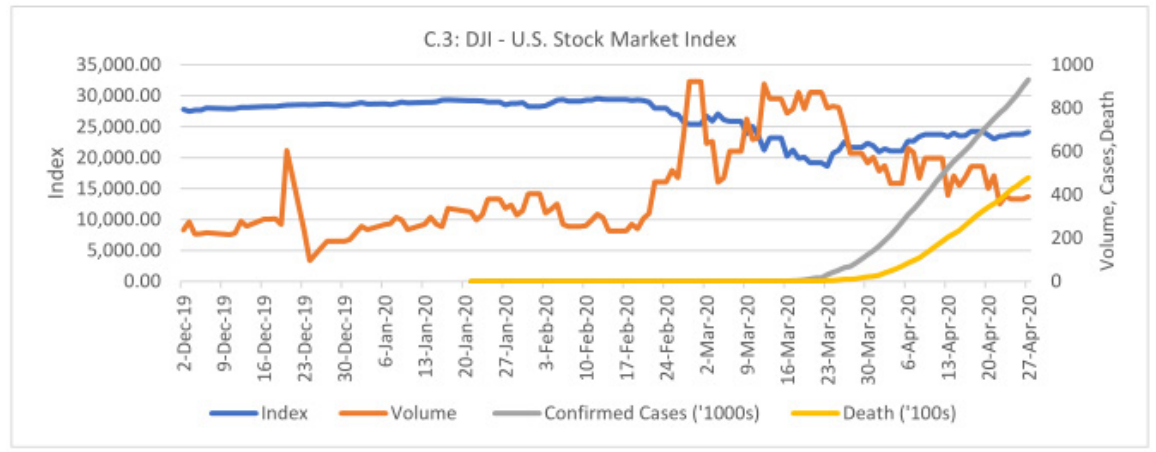

Note: Volume is in millions

Figure C. Effect of Covid-19 on six Developed Nations stock market indices.

we found Airline and Hotel sector are the most sensitive to the WHO announcement related to COVID-19.

\subsection{Analysis of the COVID-19 Effect on the Nine Global Stock Market Indices}

In this section, we look to understand the impact of COVID-19 on the nine global stock indices. Of which three stock indices namely, NIFTY50 (India), SHCOMP (China) and JCI (Indonesia) belong to the emerging economies and six stock indices namely, DJI (U.S), FTSE (U.K), CAC (France), DAX (Germany), NKY (Japan) and KOSPI (South Korea) pertain to the developed economies. We perform analysis on how the stock price and volume of these 9 stock market indices 


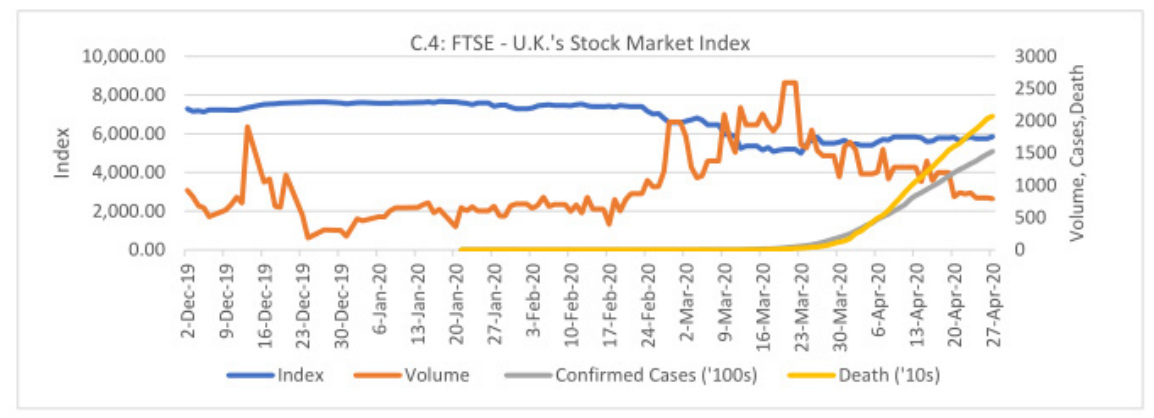

Note: Volume is in millions

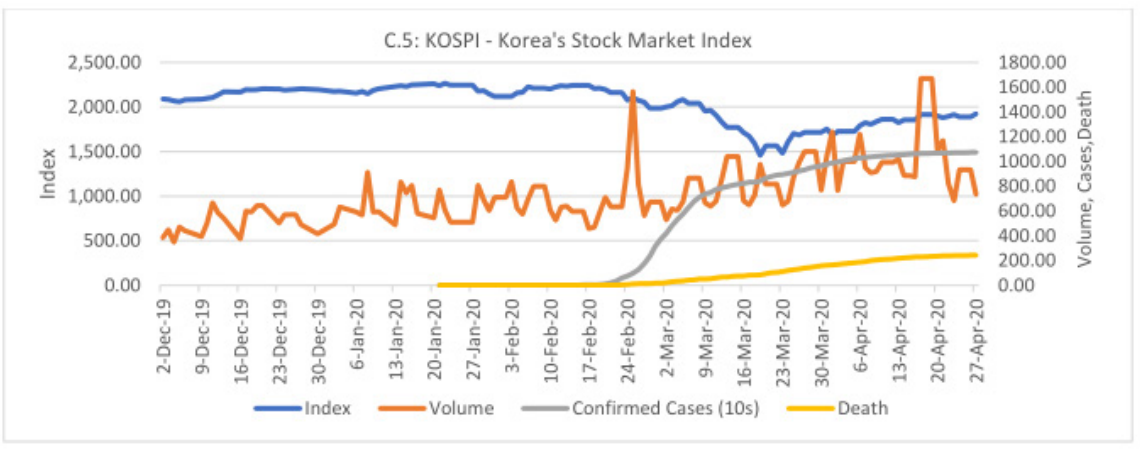

Note: Volume is in millions

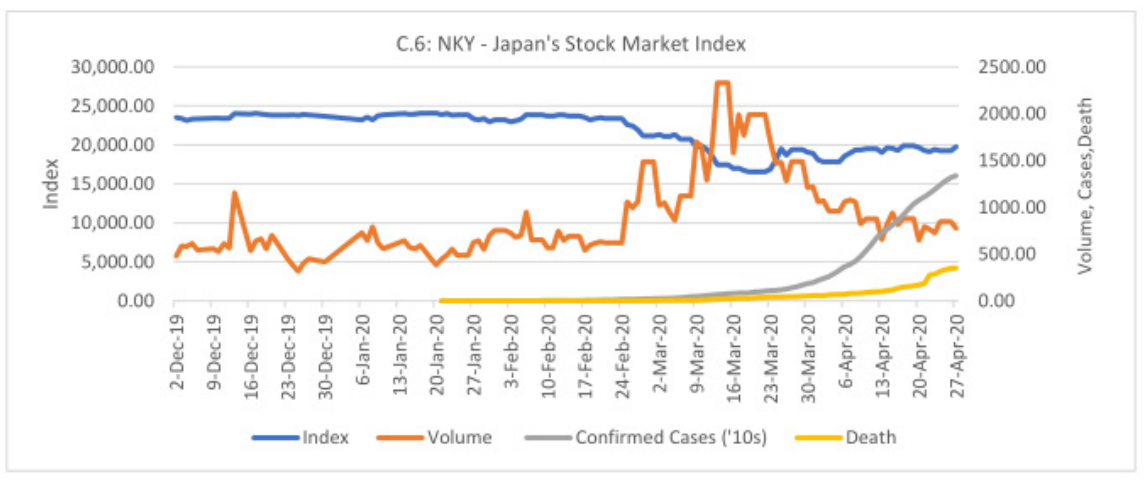

Note: Volume is in millions

Figure C. Effect of Covid-19 on six Developed Nations stock market indices. (Continued)

react to the number of COVID-19 cases and COVID-19 deaths during the period of our study.

\subsubsection{COVID-19 effect on the Stock Market and Volume for Emerging Economies.}

Figure B, shows the movement of stock prices and volumes based on COVID-19 confirmed cases and deaths for the three emerging economies, namely, India, China, and Indonesia. We see a dramatic correction in the market indices for the emerging market after midFebruary, with SHCOMP (China's stock market index) being the most volatile market. The stock market for China was closed from 24th January 2020 to 2nd February 2020. As we can see from the market index for 
SHCOMP (Figure B.2), there is a massive gap-down opening on 3rd February 2020. However, the market did correct after that fall but quickly turned downward after a few days. COVID-19 has dramatically changed the way people look at stock markets as there has been a sharp correction averaging 25 percent in a matter of a few months for NIFTY 50, SHCOMP, and JCI. There is considerable volatility in volume for most of the emerging markets as the number of confirmed cases increases. For example, the volume for NIFTY 50 (Indian stock market index), as shown in Figure B.1, increases three times compared to the previous two months average before taking a massive downward trajectory. We should not look at the index price in isolation. When comparing the market indices with volume, we find that the fall in the stock market for emerging countries is not accompanied by increasing volume. A trend is only strong if it is followed by people behind it. The curve for confirmed cases is flat for SHCOMP, which means few cases are reported daily. But still, the markets haven't recovered and have become rangebound, which shows the damage to the economy that will persist for some time. Due to the flattening of the curve in China, SHCOMP looks more stable compared to India and Indonesia.

\subsubsection{COVID-19 effect on the Stock Market and Volume for Developed Economies.}

Figure $\mathrm{C}$ shows the movement of stock prices and volumes based on COVID-19 confirmed cases and deaths of the six developed economies, namely, the US, the U.K, France, Germany, Japan, and South Korea. We observe that the developed market has had the same fate as emerging markets experiencing an average correction of 25 percent in market indices in 2020. There is a significant increase in volume for all the developed economies as the market indices fall, and subsequently, the volume decreases during the bounce-back phase. This is not a good sign for the developed market as it shows investors in the market are starting to lose confidence. Looking at the curve for confirmed cases, we find the curve is steeper for all the countries except South Korea (as seen in Figure C.5), which shows none of the countries have been able to control the outbreak. The number of confirmed cases has risen exponentially in the UK, US, France, and Germany. Hence, the curve for confirmed cases shows there could be more downside to the stock market for developed economies. Among the developed markets
South Korea and Japan have seen a relatively smaller fall in the market index averaging around 22 percent.

\section{Discussion and Conclusion}

All the Stock market indices have plunged into the correction territory at a very rapid pace even before the confirmed cases were reported in that particular country. South Korea and Japan have performed better than other developed economies during this time horizon. Some of the possible reasons could be because the curve for confirmed cases is steeper for these countries. The reasons for the better performance of South Korea and Japan could also be because these countries have issued millions of masks to the public and, thanks to strict public health measures, managed to prevent large outbreaks, despite being in such close proximity to China (Boyd, 2020). However, such claims are not supported by the WHO. They could also be benefiting from the sea border they share with the rest of the world. Sea border is stricter as there are lesser migrants and travelers can be tracked with a known history of origin. All the markets are showing strong market reactions irrespective if they are at the center or far away from this pandemic. This shows the markets move closer together during the worst of time due to an increase in globalization. The reason for such a strong market reaction is because the US and China, the two biggest economies are having the highest number of confirmed cases and are more likely to go into a recession. European countries have closed their borders and have shut down all non-essential travel (Godfrey, 2020).

In the short-run, stock prices reported a significant negative return as the health outbreak spread to different parts of the world. However, there has been a sharp bounce back due to the various measures taken to revive the economy. There are massive monetary and fiscal measures used to prevent the economies from going into recession (International Monetary Fund, 2020). The big question still looms, "are these measures strong enough to help the stock markets and bring back investor's confidence?".

The price changes tell us only one part of the story. To get the full overview of the market, we need to check how much volume is behind that price movement. Interestingly, the fall in market indices for 
emerging markets is accompanied by decreasing volume, which suggests that people are still optimistic about the future trend. Looking at price volume action together, the emerging markets don't look in too much of a bad shape. However, the same cannot be said about the developed economies as the fall in stock market indices are accompanied by increasing volume, which could be due to many factors such as the risk of a recession, panic selling, pessimistic view regarding COVID-19, etc.

COVID-19 has taken all the economies by surprise, and at the time of writing this paper, there are 1.7 million cases, and close to 1 lakh deaths. Lockdown measures, supply chain disruption, have also led to a significant fall in stock market indices. We analyzed the short-term impact of COVID-19 on global financial stock market indices. The WHO announcements on COVID-19 does have an impact on the different sectors across world, developed and emerging economies. The sectoral performance shows that the effect of COVID-19 slowly moving towards the developed market from emerging markets as the outbreak became pandemic. We also study the movement of stock prices and volume of nine different global stock market indices (classified as developed \& emerging) based on the number of new cases and deaths due to COVID-19. The picture looks better for the emerging market as a fall in stock markets is not accompanied by volume, but the developed market has seen high volume with falling markets. These results will help analysts, mutual fund managers, and traders to make an informed decision during such outbreak.

\section{References}

Baker, T. (2020, February 5). Chinese hotels seeing steep declines from coronavirus. Hotel News Now. http://hotelnewsnow.com/Articles/300132/Chinese-hotels-seeing-steepdeclines-from-coronavirus

Ball, R., \& Brown, P. (1968). An empirical evaluation of accounting income numbers. Journal of accounting research, 6(2), 159-178. https://doi. org/10.2307/2490232

Boyd, C. (2020, April 8). Face masks do not stop healthy people from catching coronavirus and should only be worn by healthcare workers and patients, says WHO. Daily Mail. https://www.
dailymail.co.uk/news/article-8199959/Facemasks-NOT-stop-healthy-people-catchingcoronavirus-says.html

Brown, S. J., \& Warner, J. B. (1985). Using daily stock returns: The case of event studies. Journal of financial economics, 14(1), 3-31. https://doi. org/10.1016/0304-405X(85)90042-X

Central Intelligence Agency, (2018). The World Factbook. https://www.cia.gov/library/publications/resources/the-world-factbook/ fields/214.html

Dolley, J. C. (1933). Characteristics and procedure of common stock split-ups. Harvard Business Review, 11(3), 316-326.

Fama, E. F. (1981). Stock returns, real activity, inflation, and money. The American economic review, 71(4), 545-565. https://www.jstor.org/ stable/1806180

Gash, J. (2020, April 1). Coronavirus and the Developing World. Raidió Teilifís Éreann. https://www.rte.ie/news/ coronavirus/2020/0401/1127730-coronaviruscovid19-developing-world/

Godfrey, K. (2020, March 17). Continent ban coronavirus - Europe to close borders today as all non-essential travel into EU banned for month. The Sun. https://www.thesun.co.uk/ travel/11184368/eu-non-essential-travelcountries/

Hollingsworth, J. (2020, Jan 30). SARS vs Wuhan coronavirus: Here's how the outbreaks compare. CNN. http://a.msn.com/05/en-us/ $\mathrm{BBZ}$ rugN?ocid=se

Hussin A. Rothan and Siddappa N. Byrareddy, (2020). The epidemiology and pathogenesis of coronavirus disease (COVID -19) outbreak. Journal of Autoimmunity, 2020, 102433. https://doi.org/10.1016/j.jaut.2020.102433

International Labor Organization, (2018). More than 60 per cent of the world's employed population are in the informal economy. https://www.ilo.org/global/about-the-ilo/ newsroom/news/WCMS_627189/lang--en/ index.htm

International Monetary Fund, (2020). Policy responses to COVID-19. https://www.imf.org/ en/Topics/imf-and-covid19/Policy-Responses-to-COVID-19

Knox, M. (2020, April 1). COVID-19: Developing nations face different risk. Medical Xpress. https://medicalxpress.com/news/2020-04-covid-nations.html 
MacKinlay, A. C. (1997). Event studies in economics and finance. Journal of economic literature, 35(1), 13-39.

Messamore, W.E. (2020, March 19). NYSE to close trading floor after 2 positive coronavirus tests. Cable News Network. https://www.ccn.com/ nyse-to-close-trading-floor-after-2-positivecoronavirus-tests/

Nippani*, S., \& Washer, K. M. (2004). SARS: a nonevent for affected countries' stock markets?. Applied Financial Economics, 14(15), 1105-1110. https://doi.org/10.1080/0960310042000310579

Tanzi, A. (2020, January 13). Global Debt-to-GDP ratio hit an all-time high last year. Bloomberg. https://www.bloomberg.com/news/articles/2020-01-13/global-debt-to-gdp-ratio-hitan-all-time-high-last-year

Wang, M. D., \& Jolly, A. M. (2004). Changing virulence of the SARS virus: The epidemiological evidence. Bulletin of the World Health Organization, 82, 547-548.

Whitworth, J. (2020, March 19). What are nations around the world doing to combat Coronavirus? The National Interest. https://nationalinterest.org/blog/buzz/what-are-nations-aroundworld-doing-combat-coronavirus- 134422

World Health Organization (2020c). WHO, UN Foundation and partners launch first of-itskind COVID-19 Solidarity Response Fund. R https://www.who.int/news-room/detail/1303-2020-who-un-foundation-and-partnerslaunch-first-of-its-kind-covid-19-solidarityresponse-fund

World Health Organization (2020), WHO Director-General's Remarks at the Media Briefing on 2019-nCoV on 11 February 2020. https:// www.who.int/dg/speeches/detail/who-director-general-s-remarks-at-the-media-briefingon-2019-ncov-on-11-february-2020

World Health Organization (WHO), (2020a). Naming the coronavirus disease (COVID-19) and the virus that causes it. https://www.who.int/emergencies/diseases/novel-coronavirus-2019/technical-guidance/naming-the-coronavirus-disease-(covid-2019)-and-the-virus-that-causes-it

World HealthOrganization,(2020b).Situation Report. https://www.who.int/emergencies/diseases/ novel-coronavirus-2019/situation-reports 


\section{Appendix}
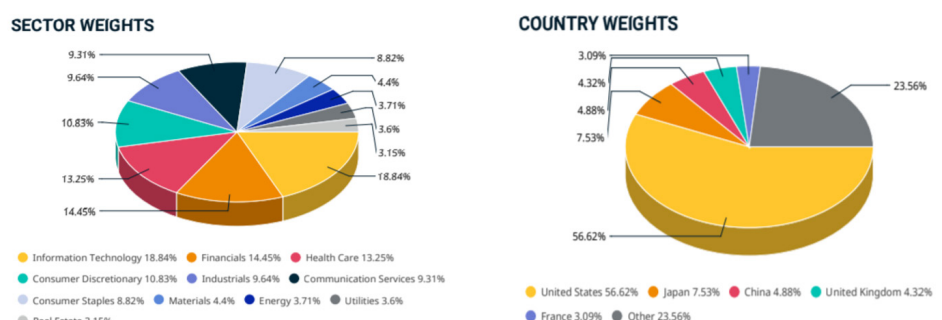

- Real Estate 3.1.15\%

Figure 2. Sector \& country weights for MSCI ACWI.

Source: https://www.msci.com/documents/10199/8d97d244-4685-4200-a24c-3e2942e3adeb

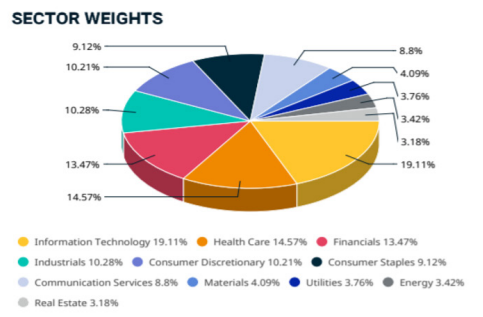

\section{COUNTRY WEIGHTS}

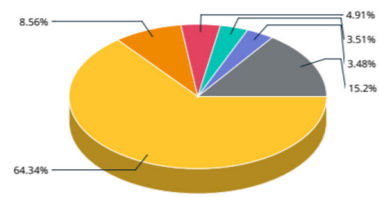

United Strtes 64.34\% - Japan 8.56\% - United Kingdom 4.91\% - France 3.51\%

- Switzerland 3.48\% — Other 15.2\%

Figure 3. Sector \& country weights for MSCI World:Source:

Source: https://www.msci.com/documents/10199/149ed7bc-316e-4b4c-8ea4-43fcb5bd6523 


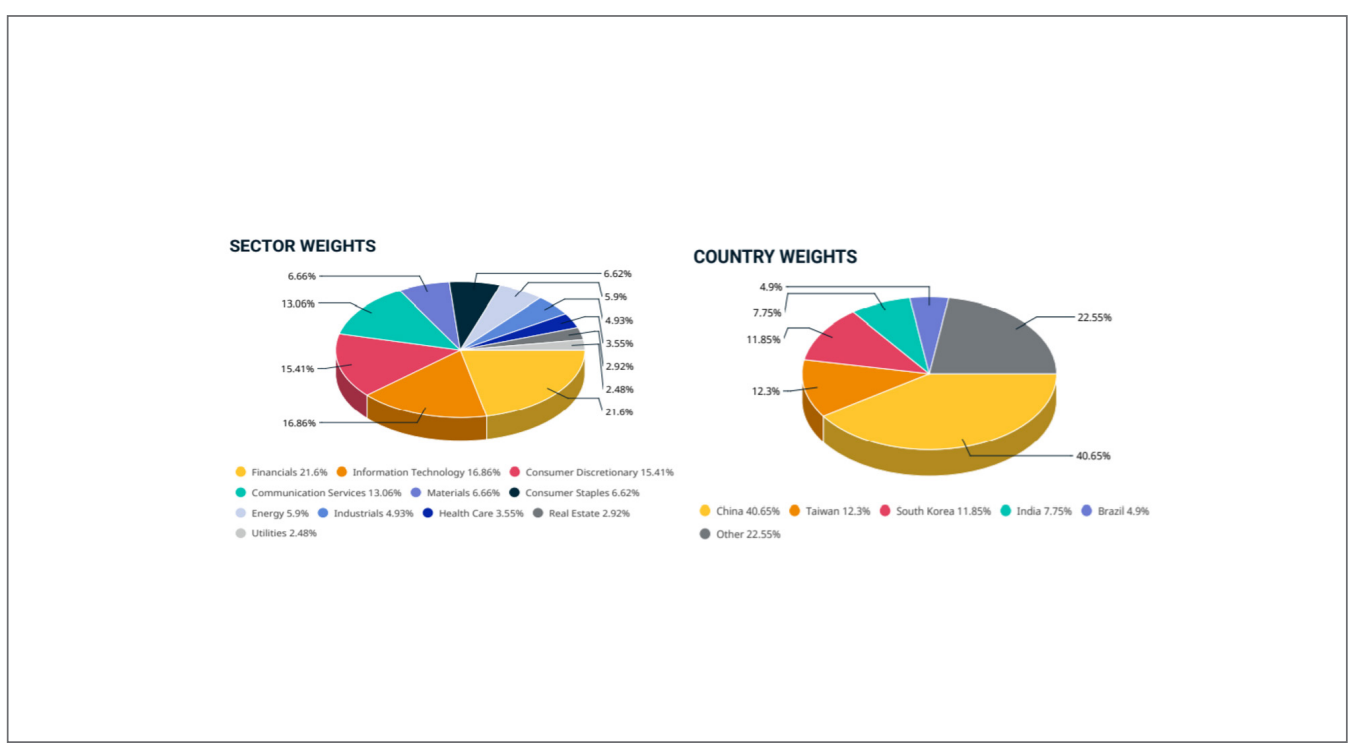

Figure 4. Sector \& country weights for MSCI Emerging Markets:

Source:: https://www.msci.com/documents/10199/c0db0a48-01f2-4ba9-ad01-226fd5678111 